\title{
Citrus growers vary in their adoption of biological control
}

by Kelly A. Grogan and Rachael E. Goodhue

In a spring 2010 survey, we investigated the characteristics that influenced whether California growers controlled major citrus pests with beneficial insects. We also performed statistical analysis of growers' reliance on Aphytus melinus, a predatory wasp, to control California red scale. The survey results suggest that growers with greater citrus acreage and more education are more likely to use biological control. Marketing outlets, ethnicity and primary information sources also influenced the extent of reliance on beneficial insects. In Probit model analysis, respondents with greater citrus acreage were more likely to incorporate A. melinus into their pest management, as well as those with more education and higher-valued crops. Information sources and growing region also had statistically significant effects.

\footnotetext{
lthough many university extension Aprograms emphasize integrated pest management (IPM), it has been unevenly adopted across regions and crops, and chemical control is still the primary method in much of the United States (Smith and Kennedy 2002). Encouragingly, many California citrus growers have incorporated biological control (biocontrol) - the use of predaceous, parasitic or pathogenic organisms - into their IPM programs. At the peak, in 1997, about $30 \%$ of citrus growers used biological control in the San Joaquin Valley, which contains the majority of California citrus acreage (Morse et al. 2006). Little data on citrus growers' biological or cultural pestcontrol decisions exist. To fill this gap and help Cooperative Extension programs promote the increased use of biological control, we surveyed California citrus growers in spring 2010 regarding their pest management decisions and analyzed the extent to which they used beneficial insects to help control the major citrus
}

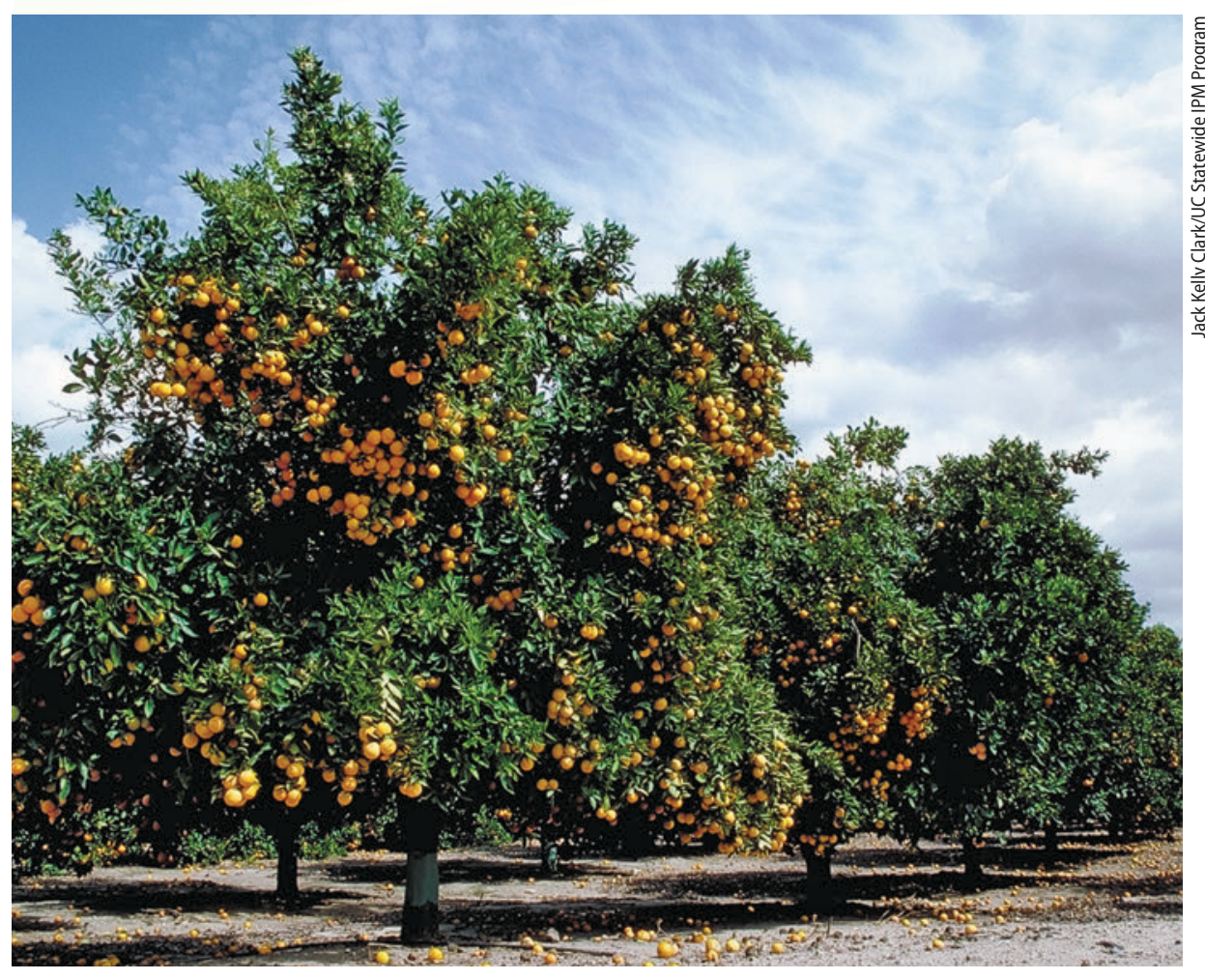

Growers in the main citrus-growing regions of California were surveyed about their pest control practices and their use of biological control for four important pests. Above, an orange grove at UC's Lindcove Research and Extension Center, near Visalia in the Central Valley.

pests: California red scale, citrus red mite, citrus thrips and cottony cushion scale.

We surveyed growers in California's main citrus-growing regions, as categorized by UC Cooperative Extension (UCCE): the San Joaquin Valley (mainly the southeastern portion), CoastalIntermediate (San Luis Obispo County to the San Diego-Mexico border), Interior (western Riverside and San Bernardino counties and inland areas of San Diego, Los Angeles and Orange counties) and Desert (Coachella and Imperial valleys) (UCCE 2003). We also included growers in the relatively small Northern citrus-growing region (Glenn and Butte counties).

\section{Natural enemies of citrus pests}

We inquired in detail about the use of biological control agents for four important citrus pests.

California red scale. California red scale sucks on plant tissue, damaging fruit, leaves, twigs and branches. Damaged fruit receive lower prices from packinghouses (Grafton-Cardwell et al. 2009). A parasitic wasp, Aphytus melinus, lays its eggs under California red scale, a primary citrus pest in the San Joaquin Valley and the Coastal-Intermediate and Interior regions. When the egg under the scale hatches, the larva eats the scale and the scale dies. Produced by commercial insectaries, A. melinus can be purchased and released relatively inexpensively (Fake et al. 2008; O'Connell et al. 2010; UC IPM 2003). Some pesticides that control California red scale and other pests, such as citricola scale and a variety of ant species, negatively affect the wasp. Selective pesticides such as narrow range oil or the insect growth regulator pyriproxyfen have little effect on $A$. melinus, so the naturally occurring population is conserved.

Reliance on control provided by A. melinus in the San Joaquin Valley is hampered by climatic factors that impede its reproduction (Hoffmann and Kennett

Originally published online only.

http://californiaagriculture.ucanr.org/ landingpage.cfm?article=ca.E.v066n01p29\&fulltext=yes DOI: 10.3733/ca.E.v066n01p29 
1985; Kennett and Hoffmann 1985; Luck 1995; Yu and Luck 1988). Other natural enemies include the parasitic wasps Aphytis lingnanensis and Comperiella bifasciata, which help control red scale in the Coastal-Intermediate and San Joaquin Valley regions, respectively. Several lady beetles also consume red scale (GraftonCardwell et al. 2009).

Citrus red mite. Citrus red mite, a primary pest in the San Joaquin Valley and Interior regions, feeds on citrus leaves, damaging them and causing leaf drop and twig dieback (Grafton-Cardwell et al. 2009). Several species in the Euseius genus of predatory mites, including E. tularensis, help control citrus red mite by consuming the pest. Euseius mites, when sufficient populations exist, are quite effective at reducing citrus red mite (Kennett et al. 1979; McMurtry et al. 1979).

Citrus thrips. Citrus thrips puncture and feed on the rind of citrus, leaving scars that get larger as the fruit grow (Grafton-Cardwell et al. 2009). Several studies suggest that Euseius also provides some control of citrus thrips (Congdon and McMurtry 1988; Grafton-Cardwell et al. 1995, 1999; Grafton-Cardwell and Ouyang 1995a). However, Jones and Morse (1995) found evidence that thrips control by E. tularensis is limited. Unlike A. melinus, E. tularensis is not commercially available (Weeden et al. 2007). Euseius population levels tend to be higher on new growth, so growers can encourage populations through pruning, which stimulates new growth (GraftonCardwell and Ouyang 1995b). They can also conserve Euseius populations by applying only selective pesticides, such as abamectin and spinosad (Success), when necessary for citrus thrips control (Grafton-Cardwell et al. 1995; Khan and Morse 2006).

Cottony cushion scale. In the late 19th century, cottony cushion scale, an invasive pest, threatened to eliminate the California citrus industry. Cottony cushion scale reduces tree health by feeding on phloem sap from twigs, leaves and branches (Grafton-Cardwell et al. 2009). Entomologists went to Australia, where cottony cushion scale originated, to find its natural enemies. In winter 1888-1889, the vedalia beetle (Rodolia cardinalis) was brought to California and released, and cottony cushion scale was under full control in areas of release by fall 1889 (Weeden et al. 2007).

Vedalia beetle spread throughout the state's citrus-growing regions and completely controls cottony cushion scale, unless its populations are suppressed or eliminated by the application of pesticides that are toxic to it. Vedalia beetle is not sold commercially. However, few adults are required to establish a population; UC Pest Management Guidelines recommend collecting vedalia beetles at any stage of development from other orchards (Grafton-Cardwell et al. 2009).

\section{Citrus grower survey}

We obtained citrus grower addresses from agricultural commissioner offices in 18 counties, which together contain $99.3 \%$ of California citrus acreage (USDA 2008). The survey was mailed on March 18, 2010, to 3,959 growers, and a reminder postcard was mailed on April 15, 2010. Of these, 348 surveys and an additional 28 postcards were undeliverable. Eighty-eight people responded that they did not produce citrus, no longer produced citrus, were in the citrus industry but had no acreage, or had less than 1 acre of citrus production for personal use. Additionally, three farm managers who managed several farms each consolidated information on all their acreage onto one form. As a result, we mailed 3,480 surveys to individuals who presumably had citrus production in 2009 and could have responded. Of these, 429 growers responded by June 3, 2010, a $12.3 \%$ response rate.

The Northern region had $3.7 \%$ of respondents and $0.5 \%$ of reported acreage; the San Joaquin Valley had 35.9\% of respondents and $67.2 \%$ of reported acreage; the Coastal-Intermediate region had $51.0 \%$ of respondents and $25.8 \%$ of reported acreage; the Interior region had $7.9 \%$ of respondents and $5.7 \%$ of reported acreage; and the Desert region had $1.4 \%$
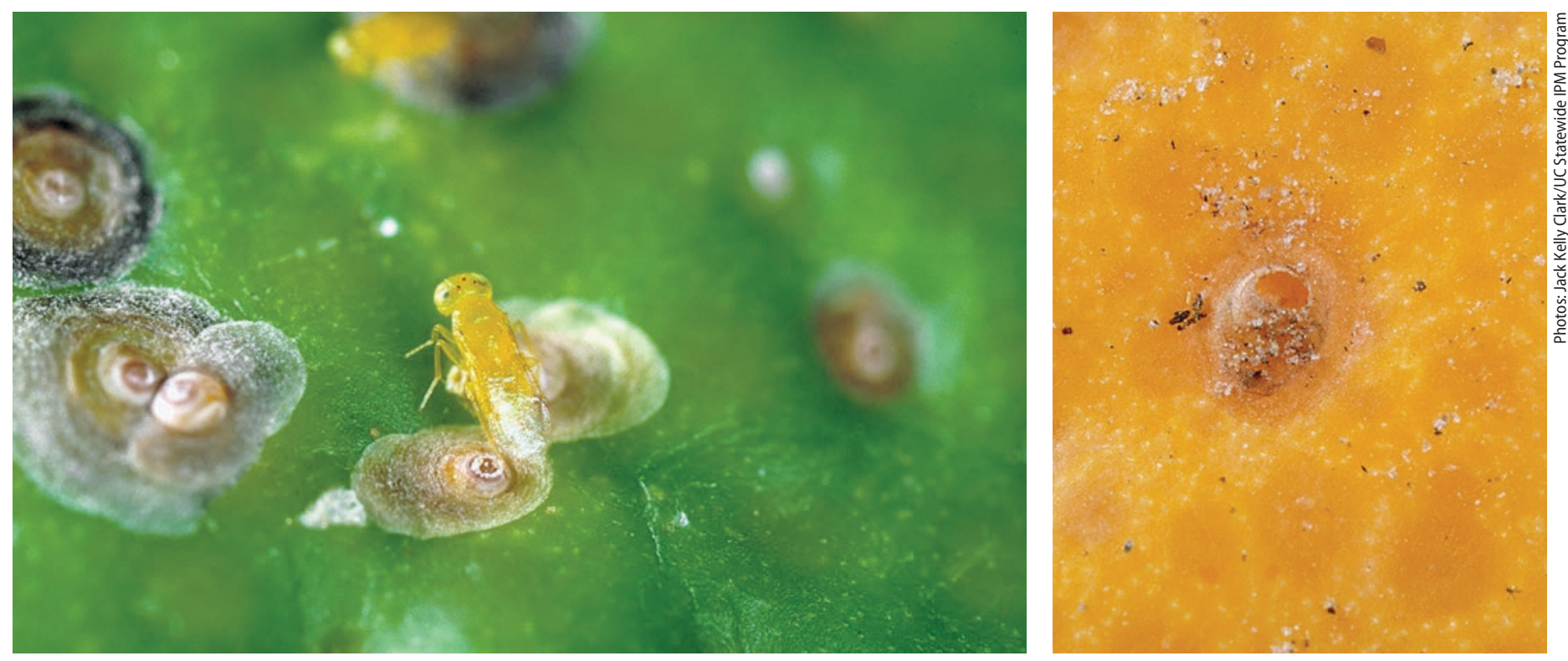

California red scale sucks on plant tissues and damages citrus fruit, leaves and branches. Left, Aphytis melinus, a parasitic wasp, oviposits in the scale. Right, the parasitized scale shows the $A$. melinus exit hole. The presence of this biological control agent may limit the need for insecticide applications. 
of respondents and $0.9 \%$ of reported acreage. No responses were received from Imperial or Kern counties, but all other counties with citrus acreage reported by the USDA were represented. The distribution of respondent acreage across counties in the survey was close to USDA estimates for Tulare and Santa Barbara counties, a little high for Madera and Ventura counties, and a little low for Fresno and Kern counties (table 1).

The survey was nine pages with 35 questions, including filling in tables of information, multiple-choice and open-ended questions. The survey was administered in 2010, and all the questions asked about the prebloom-to-harvest season of 2009. One section addressed the management of four major citrus pests (California red scale, citrus red mite, citrus thrips and cottony cushion scale) and whether any insecticides were applied if the pest was present. We asked about the presence of three important natural enemies; the degree of grower reliance on these natural enemies for pest control; and natural enemy releases during the season. Other questions addressed the implementation of cultural control methods, such as dust reduction, pruning, cover crops and sources of pest control information.

Other sections inquired about characteristics of the operation, including the amount of citrus acreage, acreage of other crops and livestock numbers, prices received and how much citrus was sold to various outlets. The final set of questions

\begin{tabular}{|c|c|c|c|c|}
\hline \multicolumn{5}{|c|}{$\begin{array}{l}\text { TABLE 1. Survey respondents' citrus acreage, 2009, and } \\
2008 \text { USDA county citrus acreage }\end{array}$} \\
\hline County & $\begin{array}{l}\text { Respondents' } \\
\text { reported } \\
\text { acreage } \\
2009^{*}\end{array}$ & $\begin{array}{l}\text { Percentage of total } \\
\text { acreage reported }\end{array}$ & $\begin{array}{c}\text { USDA } \\
\text { county } \\
\text { acreage } \\
2008^{*}\end{array}$ & $\begin{array}{c}\text { Percentage } \\
\text { of total USDA } \\
\text { acreage } 2008\end{array}$ \\
\hline & & $\%$ & & $\%$ \\
\hline Butte & 68 & 0.2 & 201 & 0.1 \\
\hline Fresno & 1,354 & 4.0 & 32,928 & 12.2 \\
\hline Glenn & 91 & 0.3 & 447 & 0.2 \\
\hline Imperial† & 0 & 0.0 & 7,133 & 2.6 \\
\hline Kern & 2,424 & 7.1 & 53,484 & 19.9 \\
\hline Kings & 0 & 0.0 & $<200$ & 0.0 \\
\hline Madera§ & 5,666 & 16.6 & 6,451 & 2.4 \\
\hline Orange & 38 & 0.1 & 446 & 0.2 \\
\hline Riverside & 895 & 2.6 & 18,280 & 6.8 \\
\hline $\begin{array}{l}\text { San } \\
\text { Bernardino }\end{array}$ & 1,248 & 3.7 & 3,775 & 1.4 \\
\hline San Diego & 1,794 & 5.3 & 10,091 & 3.7 \\
\hline $\begin{array}{l}\text { San Luis } \\
\text { Obispo }\end{array}$ & 221 & 0.6 & 1,774 & 0.7 \\
\hline $\begin{array}{l}\text { Santa } \\
\text { Barbara }\end{array}$ & 184 & 0.5 & 1,460 & 0.5 \\
\hline Stanislaus & 0 & 0.0 & 293 & 0.1 \\
\hline Tulare & 13,497 & 39.6 & 105,194 & 39.1 \\
\hline Ventura & 6,631 & 19.4 & 27,314 & 10.1 \\
\hline Total & 34,111 & 100.0 & 269,271 & 100.0 \\
\hline
\end{tabular}

addressed demographics, experience and the share of agricultural and citrus production in the household's total income.

\section{Pest presence and biological control usage}

Citrus thrips. Citrus thrips was the most common pest, with $54.8 \%$ of respondents reporting it present (table 2). Citrus thrips was most common in the San Joaquin Valley and least common in the Coastal-Intermediate region. Respondents were more likely to rely on insecticidal control for citrus thrips than other pests; $30.6 \%$ of all respondents (more than half of those with citrus thrips present) applied at least one insecticide for this pest, and insecticidal control was most common in the San Joaquin Valley.

California red scale. California red scale was the second most common pest, with $47.7 \%$ of all respondents reporting its presence (table 2). The pest was most common in the Northern

TABLE 2. Pests present and insecticides applied by survey respondents

\begin{tabular}{|c|c|c|c|c|}
\hline \multirow[b]{2}{*}{ Pest } & \multirow[b]{2}{*}{$\begin{array}{l}\text { Pest not } \\
\text { present* }\end{array}$} & \multicolumn{3}{|c|}{ Pest present } \\
\hline & & $\begin{array}{c}\text { No } \\
\text { insecticide }\end{array}$ & Insecticide & Total \\
\hline \multicolumn{5}{|l|}{ Citrus thrips } \\
\hline All regions (389)† & 45.2 & 24.2 & 30.6 & 54.8 \\
\hline Northern (15) & 26.7 & 40.0 & 33.3 & 73.3 \\
\hline San Joaquin Valley (133) & 14.3 & 16.5 & 69.2 & 85.7 \\
\hline Coastal-Intermediate (202) & 67.3 & 27.2 & 5.4 & 32.6 \\
\hline Interior (32) & 50.0 & 21.9 & 28.1 & 50.0 \\
\hline Desert (5) & 0.0 & 80.0 & 20.0 & 100.0 \\
\hline \multicolumn{5}{|l|}{ California red scale } \\
\hline All regions (394) & 52.3 & 28.9 & 18.8 & 47.7 \\
\hline Northern (15) & 40.0 & 33.3 & 26.7 & 60.0 \\
\hline San Joaquin Valley (136) & 40.4 & 26.5 & 33.1 & 59.6 \\
\hline Coastal-Intermediate (204) & 60.8 & 28.9 & 10.3 & 39.2 \\
\hline Interior (32) & 50.0 & 40.6 & 9.4 & 50.0 \\
\hline Desert (5) & 80.0 & 0.0 & 20.0 & 20.0 \\
\hline \multicolumn{5}{|l|}{ Citrus red mite } \\
\hline All regions (393) & 69.4 & 23.5 & 7.1 & 30.6 \\
\hline Northern (14) & 85.7 & 14.3 & 0.0 & 14.3 \\
\hline San Joaquin Valley (136) & 62.5 & 22.8 & 14.7 & 37.5 \\
\hline Coastal-Intermediate (207) & 71.0 & 25.6 & 3.4 & 29.0 \\
\hline Interior (32) & 78.1 & 18.8 & 3.1 & 21.9 \\
\hline Desert (4) & 100.0 & 0.0 & 0.0 & 0.0 \\
\hline \multicolumn{5}{|l|}{ Cottony cushion scale } \\
\hline All regions (391) & 70.1 & 27.1 & 2.8 & 29.9 \\
\hline Northern (16) & 68.8 & 31.3 & 0.0 & 31.3 \\
\hline San Joaquin Valley (135) & 60.7 & 34.1 & 5.2 & 39.3 \\
\hline Coastal-Intermediate (203) & 77.3 & 20.7 & 2.0 & 22.7 \\
\hline Interior & 64.5 & 35.5 & 0.0 & 35.5 \\
\hline Desert (4) & 75.0 & 25.0 & 0.0 & 25.0 \\
\hline
\end{tabular}


and San Joaquin Valley regions and least common in the Desert and CoastalIntermediate regions. Less than half of respondents who reported California red scale present chose to apply a pesticide. (This may be due to the effect of a pesticide application persisting for more than 1 year; respondents who treated the previous year would have been unlikely to report an application in the 2009-2010 season.)

As with citrus thrips, insecticidal control of California red scale was most common in the San Joaquin Valley. This is consistent with UC IPM guidelines, which state that biological control of California red scale is most effective in coastal

\section{TABLE 3. Presence of natural enemies reported by survey respondents}

\begin{tabular}{|c|c|c|c|}
\hline Natural enemy & $\begin{array}{l}\text { Naturally } \\
\text { occurring }\end{array}$ & $\begin{array}{c}\text { Not } \\
\text { naturally } \\
\text { occurring }\end{array}$ & Unknown \\
\hline & & ..\% & $\cdots$ \\
\hline \multicolumn{4}{|l|}{ Vedalia beetle } \\
\hline All regions $(284)^{*}$ & 26.8 & 24.6 & 48.6 \\
\hline Northern (8) & 50.0 & 12.5 & 37.5 \\
\hline $\begin{array}{l}\text { San Joaquin } \\
\text { Valley (71) }\end{array}$ & 5.6 & 25.4 & 69.0 \\
\hline $\begin{array}{l}\text { Coastal- } \\
\text { Intermediate } \\
\text { (139) }\end{array}$ & 16.5 & 30.9 & 52.5 \\
\hline Interior (23) & 26.1 & 30.4 & 43.5 \\
\hline Desert (2) & 0.0 & 50.0 & 50.0 \\
\hline \multicolumn{4}{|l|}{ Aphytis melinus } \\
\hline All regions (310) & 22.3 & 26.5 & 51.3 \\
\hline Northern (9) & 33.3 & 22.2 & 44.4 \\
\hline $\begin{array}{l}\text { San Joaquin } \\
\text { Valley (113) }\end{array}$ & 26.5 & 23.9 & 49.6 \\
\hline $\begin{array}{l}\text { Coastal- } \\
\text { Intermediate } \\
(160)\end{array}$ & 16.9 & 30.0 & 53.1 \\
\hline Interior (25) & 36.0 & 20.0 & 44.0 \\
\hline Desert (1) & 0.0 & 0.0 & 100.0 \\
\hline \multicolumn{4}{|l|}{ Euseius tularensis } \\
\hline All regions (329) & 21.9 & 21.0 & 57.1 \\
\hline Northern (10) & 30.0 & 20.0 & 50.0 \\
\hline $\begin{array}{l}\text { San Joaquin } \\
\text { Valley (124) }\end{array}$ & 29.0 & 16.9 & 54.0 \\
\hline $\begin{array}{l}\text { Coastal- } \\
\text { Intermediate } \\
\text { (163) }\end{array}$ & 16.6 & 25.2 & 58.3 \\
\hline Interior (27) & 22.2 & 18.5 & 59.3 \\
\hline Desert (3) & 0.0 & 0.0 & 100.0 \\
\hline
\end{tabular}

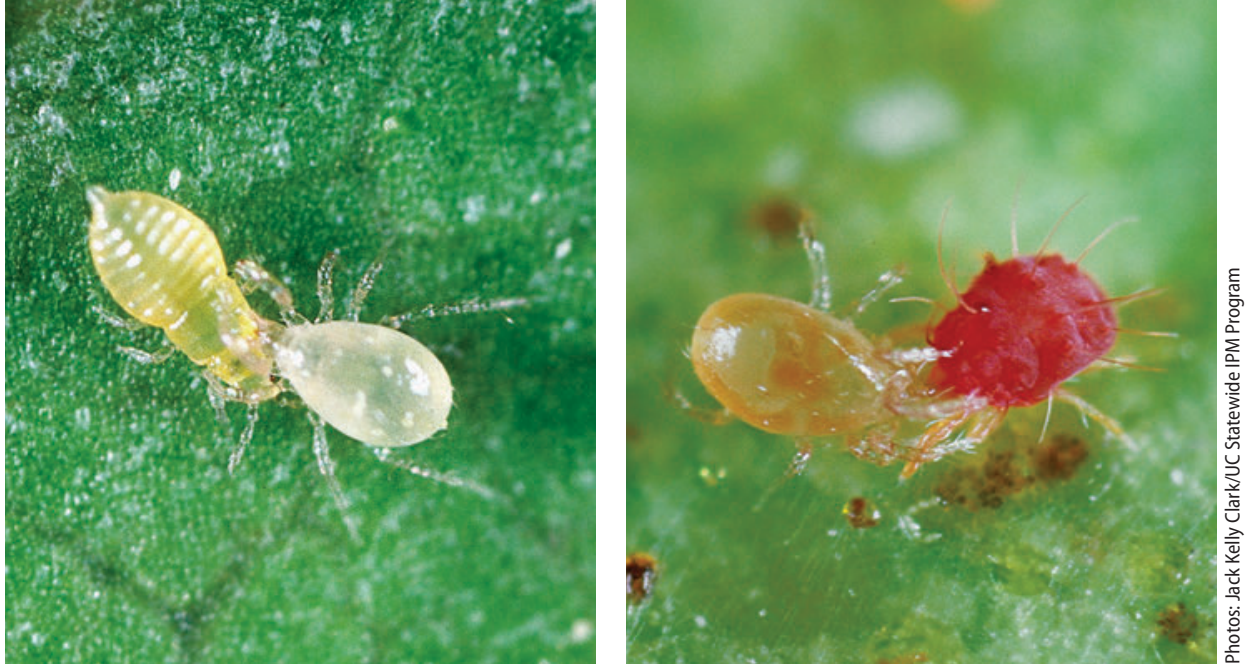

Natural enemies of pest insects can help control crop damage. Euseius tularensis is a mite that feeds on, left, citrus thrips, and, right, citrus red mite, both important citrus pests.

areas (and some inland areas of Southern California) and that California red scale has been suppressed through a pesticide eradication program in the Desert region.

The reported natural occurrence of A. melinus - the biological control agent for California red scale - was most common in the Interior and Northern regions and least common in Desert and CoastalIntermediate regions (table 3); this may be partially due to regional differences in the presence of California red scale. Forty-seven respondents purchased and released $A$. melinus to control California red scale, about one-quarter of those who reported the pest present (table 4). These 47 growers made an average of four releases (data not shown), the majority in the Coastal-Intermediate and San Joaquin Valley regions.

\section{Citrus red mite and cottony cushion} scale. Citrus red mite and cottony cushion scale had similar prevalence, $30.6 \%$ and $29.9 \%$, respectively (table 2 ). Citrus red mite was most common in the San Joaquin Valley and least common in the

\begin{tabular}{|c|c|c|c|c|c|}
\hline \multirow[b]{2}{*}{ Natural enemy/pest } & \multirow{2}{*}{$\begin{array}{l}\text { Pest not } \\
\text { present }\end{array}$} & \multicolumn{4}{|c|}{ Degree of reliance on natural enemy (pest present) } \\
\hline & & None & Somewhat & Mostly & Entirely \\
\hline \multicolumn{6}{|c|}{ Vedalia beetle/cottony cushion scale } \\
\hline All regions $(379)^{*}$ & 70.7 & 11.6 & 5.0 & 5.8 & 6.9 \\
\hline Northern (14) & 71.4 & 7.1 & 7.1 & 7.1 & 7.1 \\
\hline San Joaquin Valley (136) & 61.8 & 10.3 & 8.8 & 9.6 & 9.6 \\
\hline Coastal-Intermediate (195) & 76.9 & 12.8 & 3.1 & 2.6 & 4.6 \\
\hline Interior (29) & 72.4 & 6.9 & 0.0 & 10.3 & 10.3 \\
\hline Desert (4) & 75.0 & 25.0 & 0.0 & 0.0 & 0.0 \\
\hline \multicolumn{6}{|c|}{ Aphytis melinus/California red scale } \\
\hline All regions (378) & 51.6 & 22.2 & 9.3 & 5.6 & 11.4 \\
\hline Northern (13) & 61.5 & 7.7 & 7.7 & 7.7 & 15.4 \\
\hline San Joaquin Valley (132) & 40.2 & 35.6 & 9.8 & 7.6 & 6.8 \\
\hline Coastal-Intermediate (197) & 57.9 & 16.2 & 8.6 & 5.1 & 12.2 \\
\hline Interior (3) & 50.0 & 13.3 & 10.0 & 0.0 & 26.7 \\
\hline Desert (4) & 100.0 & 0.0 & 0.0 & 0.0 & 0.0 \\
\hline \multicolumn{6}{|c|}{ Euseius tularensis/citrus thrips and citrus red mite } \\
\hline All regions (369) & 45.0 & 36.0 & 7.3 & 5.4 & 6.2 \\
\hline Northern (14) & 42.9 & 28.6 & 14.3 & 7.1 & 7.1 \\
\hline San Joaquin Valley (130) & 18.5 & 55.4 & 12.3 & 7.7 & 6.2 \\
\hline Coastal-Intermediate (192) & 63.5 & 22.4 & 4.2 & 3.1 & 6.8 \\
\hline Interior (28) & 50.0 & 32.1 & 3.6 & 10.7 & 3.6 \\
\hline Desert & 0.0 & 100.0 & 0.0 & 0.0 & 0.0 \\
\hline
\end{tabular}




\section{The majority of survey respondents who reported having} cottony cushion scale or California red scale also reported using
biological control.

Desert region, while cottony cushion scale was most common in the San Joaquin Valley and least common in the CoastalIntermediate region.

Only $7.1 \%$ and $2.8 \%$ of respondents applied a pesticide to control citrus red mite and cottony cushion scale, and these respondents were only $23 \%$ and $9 \%$ of respondents with these pests present, respectively. For citrus red mite, healthy orchards with abundant natural enemies, such as E. tularensis, may be able to tolerate high populations of both pests without suffering economic damage (Grafton-Cardwell et al. 2009). Vedalia beetle and Cryptochaetum iceryae (in coastal areas) keep cottony cushion scale under control in most orchards, when not disrupted by pesticides (Grafton-Cardwell et al. 2009). The reported natural occurrence of E. tularensis was highest in the Northern and San Joaquin Valley regions, and lowest in the Desert and CoastalIntermediate regions (table 3).

Although cottony cushion scale was the least commonly reported pest (table 2 ), vedalia beetle was the most commonly reported natural enemy (table 3). Vedalia beetle consumes only cottony cushion scale and cannot survive without this food source. Cottony cushion scale was likely present in more orchards, with vedalia beetle keeping it below detectable thresholds.

Reliance on biological control. We asked growers about the degree to which they relied on vedalia beetle, $A$. melinus and E. tularensis for pest control. While $26.8 \%$ reported having vedalia beetle present (table 3), only 17.7\% reported any degree of reliance on it for cottony cushion scale control (table 4). Reliance on vedalia beetle was most common in the San Joaquin Valley, where cottony cushion scale was most prevalent. For California red scale control, $26.3 \%$ relied on A. melinus to some extent. Only $18.9 \%$ of respondents reported relying on E. tularensis for citrus red mite or citrus thrips control; more than one-third reported they had citrus thrips or citrus red mite and had not relied on the predatory mite for control, which could be due to their not knowing that $E$. tularensis was present.

\section{Determinants for using biocontrol}

We performed a statistical analysis of three groups of respondents: (1) all respondents, (2) those who incorporated some biological control into their pest management programs and (3) those who released A. melinus. Although large standard errors for most variables prevented statistical significance of the difference in means, the survey results did show trends (table 5). Respondents who relied to at least some extent on beneficial insects for control had substantially more citrus acreage than the average respondent. The average years of farming experience was slightly higher for respondents reporting some degree of reliance on $A$. melinus than for the average respondent, and even higher for those reporting some degree of reliance on vedalia beetle and E. tularensis.

Smaller shares of Asian and Latino respondents indicated any reliance on pest control provided by A. melinus. The

\begin{tabular}{|c|c|c|c|c|c|}
\hline \multicolumn{6}{|c|}{$\begin{array}{c}\text { TABLE 5. Characteristics of survey respondents and those who relied on } \\
\text { or released natural enemies: Summary statistics }\end{array}$} \\
\hline & $\begin{array}{l}\text { All } \\
\text { respondents }\end{array}$ & $\begin{array}{l}\text { Relied on } \\
\text { wasp }\end{array}$ & $\begin{array}{l}\text { Released } \\
\text { wasp }\end{array}$ & $\begin{array}{l}\text { Relied on } \\
\text { beetle }\end{array}$ & $\begin{array}{l}\text { Relied on } \\
\text { mite }\end{array}$ \\
\hline Number of respondents & 422 & 93 & 47 & 67 & 70 \\
\hline \multicolumn{6}{|l|}{ Farm characteristics } \\
\hline Nonorange acreage (\%) & 39.1 & 38.8 & 37.0 & 34.7 & 35.9 \\
\hline Average total citrus acres & 76.4 & 224.7 & 402.1 & 199.0 & 253.0 \\
\hline Average total acres & 167.6 & 347.0 & 632.9 & 295.3 & 346.5 \\
\hline Average expected value per acre (\$) & 6,242 & 6,445 & 6,841 & 5,945 & 6,525 \\
\hline Growers with organic acreage (\%) & 14.5 & 10.8 & 6.4 & 9.0 & 8.6 \\
\hline \multicolumn{6}{|l|}{ Grower characteristics } \\
\hline Median education level & $\begin{array}{l}\text { College } \\
\text { degree }\end{array}$ & $\begin{array}{l}\text { College } \\
\text { degree }\end{array}$ & $\begin{array}{l}\text { College } \\
\text { degree }\end{array}$ & $\begin{array}{l}\text { College } \\
\text { degree }\end{array}$ & $\begin{array}{l}\text { College } \\
\text { degree }\end{array}$ \\
\hline Average experience (years) & 25.7 & 29.9 & 29.4 & 33.5 & 32.8 \\
\hline Female (\%) & 18.0 & 14.9 & 15.9 & 12.1 & 10.0 \\
\hline \multicolumn{6}{|l|}{ Race (\%) } \\
\hline White & 86.4 & 90.9 & 93.2 & 84.9 & 83.5 \\
\hline Asian & 3.6 & 1.1 & 0.0 & 3.0 & 6.0 \\
\hline Latino & 6.4 & 3.4 & 2.3 & 4.5 & 3.0 \\
\hline Other & 3.6 & 4.6 & 4.5 & 7.6 & 7.5 \\
\hline \multicolumn{6}{|l|}{ Output sold through outlet (\%) } \\
\hline Packinghouse/shipper & 65.0 & 78.7 & 88.3 & 80.5 & 75.4 \\
\hline Processor & 6.2 & 2.4 & 3.0 & 2.2 & 0.3 \\
\hline Other & 21.7 & 3.3 & 4.3 & 1.6 & 2.9 \\
\hline \multicolumn{6}{|c|}{ Primary source of pest control information (\%) } \\
\hline Pest control adviser & 55.3 & 70.1 & 82.2 & 67.7 & 65.6 \\
\hline Extension agent & 13.5 & 9.2 & 4.4 & 9.8 & 14.1 \\
\hline Other growers & 8.1 & 2.3 & 0.0 & 3.2 & 4.7 \\
\hline Farm/chemical suppliers & 7.2 & 0.0 & 0.0 & 1.6 & 1.6 \\
\hline Extension publications & 4.3 & 3.4 & 2.2 & 6.5 & 4.7 \\
\hline Organic certifying agent & 3.7 & 0.0 & 0.0 & 0.0 & 0.0 \\
\hline Trade magazines & 1.1 & 1.1 & 2.2 & 0.0 & 0.0 \\
\hline Other* & 6.6 & 13.8 & 8.9 & 11.3 & 9.4 \\
\hline
\end{tabular}




\begin{tabular}{|c|c|c|}
\hline \multicolumn{3}{|c|}{$\begin{array}{l}\text { TABLE 6. Grower reliance on Aphytus melinus and augmentative releases: } \\
\text { Marginal effects of Probit modelst }\end{array}$} \\
\hline Explanatory variable & $\begin{array}{l}\text { Effect on probability of grower } \\
\text { relying mostly or entirely on } \\
\text { A. melinus }\end{array}$ & $\begin{array}{l}\text { Effect on probability of } \\
\text { A. melinus release(s) }\end{array}$ \\
\hline Red scale degree-days & -5.22 & -0.90 \\
\hline Natural enemy degree-days & 8.36 & 0.88 \\
\hline \multicolumn{3}{|l|}{ Output to outlet (\%) } \\
\hline Processor & 0.07 & 0.12 \\
\hline Nonprocessor, nonpackinghouse & 0.03 & $-0.23^{*}$ \\
\hline Nonorange acres (\%) & -22.78 & -14.82 \\
\hline Expected value/acre $(\$ 1,000 s)$ & $0.04^{*}$ & $0.03^{*}$ \\
\hline Organic & -5.28 & -4.00 \\
\hline Total citrus acres & 5.73 & $5.86^{*}$ \\
\hline Total citrus acres squared & -0.06 & -0.02 \\
\hline Total acres & -8.27 & 0.18 \\
\hline Total acres squared & 0.13 & -0.01 \\
\hline Education & $63.41^{* *}$ & 18.66 \\
\hline Education squared & $-6.26^{* *}$ & -1.97 \\
\hline Experience & 0.15 & -0.09 \\
\hline Experience squared & 0.00 & 0.01 \\
\hline \multicolumn{3}{|c|}{ Primary information source (comparison base: pest control adviser) } \\
\hline Extension agent & -11.81 & $-14.38^{*}$ \\
\hline Extension publications & 27.10 & 10.45 \\
\hline Other growers & -19.17 & - \\
\hline Chemical supplier & - & - \\
\hline Trade magazine $\ddagger$ & - & 46.57 \\
\hline Other source & 16.51 & 11.65 \\
\hline Female & 12.33 & 7.33 \\
\hline \multicolumn{3}{|l|}{ Ethnicity (comparison base: white) } \\
\hline Asian & $-23.56^{*}$ & - \\
\hline Latino & $43.52^{* *}$ & 13.53 \\
\hline Other & - & $-21.46^{* * *}$ \\
\hline \multicolumn{3}{|c|}{ Region (comparison base: San Joaquin Valley) } \\
\hline Northern & 40.26 & 14.51 \\
\hline Coastal-Intermediate & $38.52^{* *}$ & 22.39 \\
\hline Interior & $51.86^{* * *}$ & $31.29^{*}$ \\
\hline Cover crop & 23.28 & 25.32 \\
\hline Hedgerow & -15.32 & $-21.36^{* * *}$ \\
\hline $\mathrm{N}$ & 154.00 & 167.00 \\
\hline Pseudo-R squared & 0.1898 & 0.2826 \\
\hline \multicolumn{3}{|c|}{${ }^{*},{ }^{* *}$ and ${ }^{* * *}$ indicate significance at the $10 \%, 5 \%$ and $1 \%$ levels, respectively. } \\
\hline \multicolumn{3}{|c|}{$\begin{array}{l}\text { † For continuous variables, percentages reported indicate how increasing the explanatory variable by one unit from its mean affects the } \\
\text { probability that a grower relies mostly or entirely on } A \text {. melinus or releases } A \text {. melinus. For binary variables (organic, information source, } \\
\text { female, ethnicity, region, cover crop, hedgerows), the percentage indicates how a move from the base category (e.g., white ethnicity) or } \\
\text { absence of a characteristic (e.g., no cover crops) to that category (e.g., Asian ethnicity) or characteristic (e.g., cover crops present) affects the } \\
\text { probability that a respondent relies mostly or entirely on A. melinus or releases A. melinus. Binary variables for which no marginal effect is } \\
\text { given were removed from the model because for each of those variables, all growers in the category did not rely on or release } A \text {. melinus. } \\
\text { A value of one for these binary variables perfectly predicts that the grower did not rely on } A \text {. melinus or release } A \text {. melinus, and the model } \\
\text { cannot be estimated with perfect predictors. }\end{array}$} \\
\hline
\end{tabular}

"other" ethnic group comprised a disproportionately large share of the groups that relied on vedalia beetle and E. tularensis compared to the entire sample. In terms of sales outlets, respondents who relied to some degree on beneficial insects sold a larger share of their output to packinghouses and a smaller share to processors and other outlets than the entire sample. Over half of all respondents (55.3\%) said pest control advisers were their primary source of information, but $65.6 \%$ to $82.2 \%$ of those who relied on beneficial insects listed pest control advisers as their primary information source.

\section{A. melinus probability analysis}

We performed statistical analysis regarding two aspects of California red scale control for the subset of respondents who reported it present during the 2009 growing season. Using a Probit model, we modeled the probability that a grower relied mostly or entirely on A. melinus for California red scale control - either by using pesticides compatible with $A$. meli$n u s$, thereby conserving the beneficial insect, or by augmenting $A$. melinus through releases of commercially produced insects. Additionally, we modeled separately the probability that a grower chose to purchase and release $A$. melinus to augment a naturally occurring population. A Probit model measures the effects of predictor or explanatory variables on the probability of an outcome occurring (e.g., augmentation of $A$. melinus); the explanatory values we tested are listed in table 6 .

Economic factors. Among the economic characteristics, an increase in the expected value of production per acre increased the probability that a respondent relied on $A$. melinus and that he or she released $A$. melinus. Both coefficients were statistically significant. Also, as the share of output sold to outlets other than processors and packinghouses - such as farmers markets, grocery wholesalers and restaurants - increased, respondents were less likely to make releases. The price effects of scale damage may differ for these outlets.

Acreage. Respondents with more acres of citrus were more likely to make releases than those with fewer acres, probably because of economies of scale. Releases must coincide with particular 


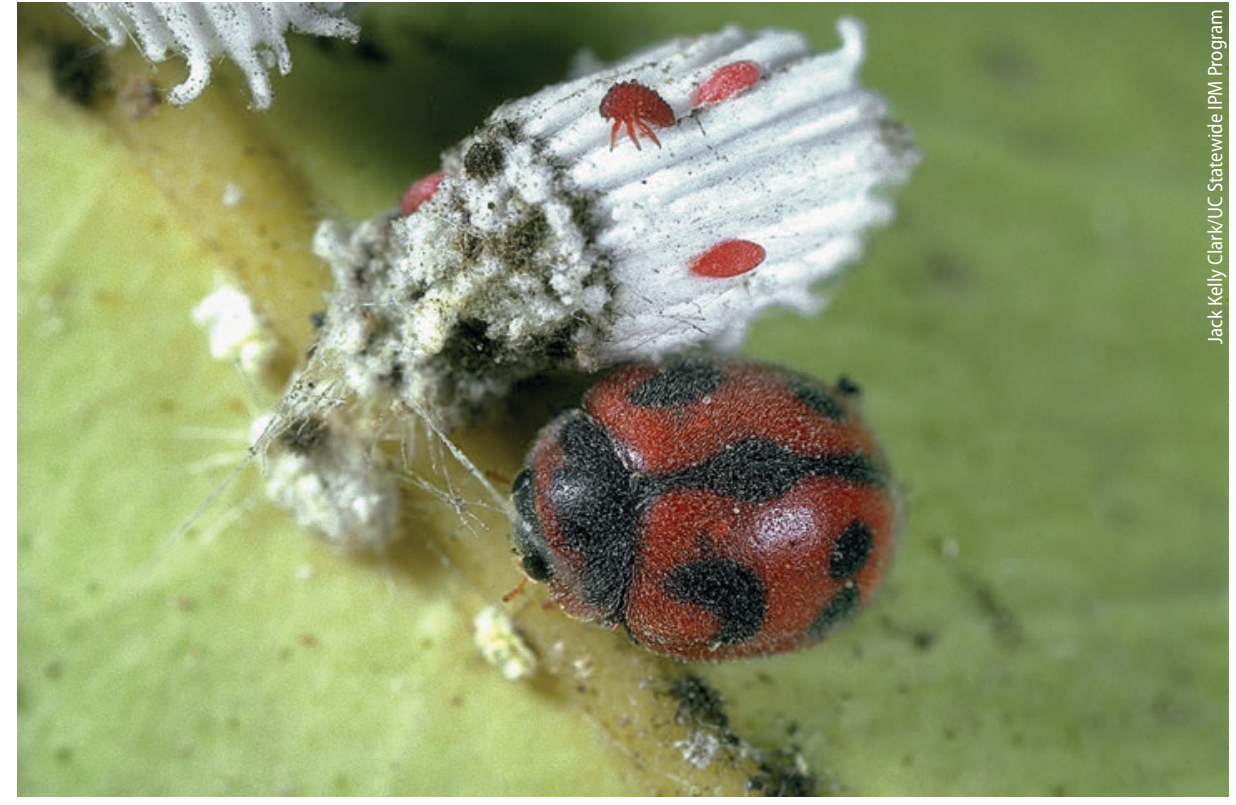

Since its introduction in 1888-1889, the vedalia beetle has successfully controlled cottony cushion scale, an invasive pest that had threatened the California citrus industry.

stages in the California red scale cycle, and the quantity needed depends on existing populations, which are determined by population dynamics and previous releases. Additionally, some pesticides that provide control of common citrus pests are toxic to A. melinus, so growers must consider their entire pest management plan when relying on A. melinus (GraftonCardwell et al. 2009). For growers with many acres of citrus, the time needed to learn about and carry out $A$. melinus treatments is more likely to yield sufficient benefits to justify the time investment than it is for growers with fewer acres.

Education. Educational attainment had a positive and statistically significant effect on the likelihood that a respondent relied mostly or entirely on $A$. melinus to control citrus red scale. The effect of educational attainment, however, leveled off at the graduate degree level.

Information sources. Primary sources of pest control information were significant predictors of both reliance on and releases of $A$. melinus. Respondents relying on Cooperative Extension agents were about $14 \%$ less likely to make releases than those relying on pest control advisers for their pest control information, and the effect was statistically significant.

Ethnicity. Grower ethnicity had statistically significant effects. Asian respondents were $24 \%$ less likely than white respondents to rely mostly or entirely on A. melinus, while Latino respondents were
$44 \%$ more likely than white respondents to rely mostly or entirely on A. melinus. Respondents of "other" ethnicity were $21 \%$ less likely to make releases than white respondents.

Region. Not surprisingly, there were regional effects. Respondents in the Coastal-Intermediate and Interior regions were $39 \%$ and $52 \%$ more likely, respectively, to rely on A. melinus than those in the San Joaquin Valley, probably because of climatic factors favoring $A$. melinus and biological control in those regions. Respondents in the Interior region were $31 \%$ more likely to make augmentative releases than those in the San Joaquin Valley. Respondents in the CoastalIntermediate and San Joaquin Valley regions had similar likelihoods of releasing A. melinus, though for different reasons: In the Coastal-Interior region, growers can likely rely on $A$. melinus without releases because of a favorable climate and the application of compatible pesticides, while growers in the San Joaquin Valley may choose not to make releases because the area's climate impedes the establishment of A. melinus.

Hedgerows. The use of hedgerows (trees or shrubs planted around a field of crops) decreased the likelihood that a respondent made releases, although only about $6 \%$ of respondents had hedgerows. Hedgerows may provide additional habitat or resources for beneficial insects or may buffer orchards from nearby use of pesticides toxic to A. melinus, decreasing the need for releases.

\section{Opportunities for UCCE}

We were able to derive a few implications about the use of biological control among citrus growers. First, many growers already incorporate biological control into their pest management plans. The majority of respondents who reported having cottony cushion scale or California red scale reported using biological control, although their degree of reliance on it varied by pest, region and respondent characteristics. Additionally, growers are willing to incorporate releases of commercially available natural enemies in their pest management plans, as evidenced by the quarter of all growers with California red scale who currently release commercially available $A$. melinus.

Besides A. melinus, other beneficial insects that we surveyed are not commercially available at this time. Vedalia beetle is not likely to be produced commercially. Given evidence that a variety of beneficial insects (including two generalist predators, lacewings and minute pirate bugs, which are currently commercially available) collectively provide some degree of biological control for citrus thrips, production and augmentative releases of E. tularensis may not be the most effective means of enhancing the biological control of citrus thrips or citrus red mite. Research suggests that pruning and leguminous cover crops help support larger populations of E. tularensis (Grafton-Cardwell 1997; Grafton-Cardwell and Ouyang 1995b). Increasing the use of these practices and resources to attract and support a variety of natural enemies may be the most cost-effective approach to biological control of citrus thrips.

Consistent with economic theory, respondents whose operations and personal characteristics predicted that they had the largest potential gains from investments of time spent learning and implementing biological control were the ones who chose to rely on biological control. If the social benefits of biological control (positive benefits to the individual grower as well as nearby growers) exceed the benefits to the individual grower, the adoption of biological control practices only by growers with an individual incentive 
to do so will result in too little biological control relative to the socially optimal level (the level at which regional profits are greatest). Comments from respondents provided anecdotal evidence of positive spillover effects from neighbors who released $A$. melinus, suggesting that the social benefits are in fact greater than the private benefits, at least in some instances.

To increase the net private benefit of using biological control, subsidies could be implemented in regions such as the Coastal-Intermediate region and parts of the San Joaquin Valley where it would be cost effective to control California red scale with $A$. melinus. Instead of direct financial subsidies, free training workshops or reminders about when key population life-cycle events are occurring in specific regions could be effective.

Currently, UCCE provides training workshops and newsletters. Our analysis suggests that expanding them could advance the use of biological control; only about $4 \%$ of respondents relied on Cooperative Extension publications as their primary source of pest control information and only $13.5 \%$ relied on a Cooperative Extension agent. The results also suggest that efforts should be made to draw more growers away from reliance on farm and chemical suppliers for

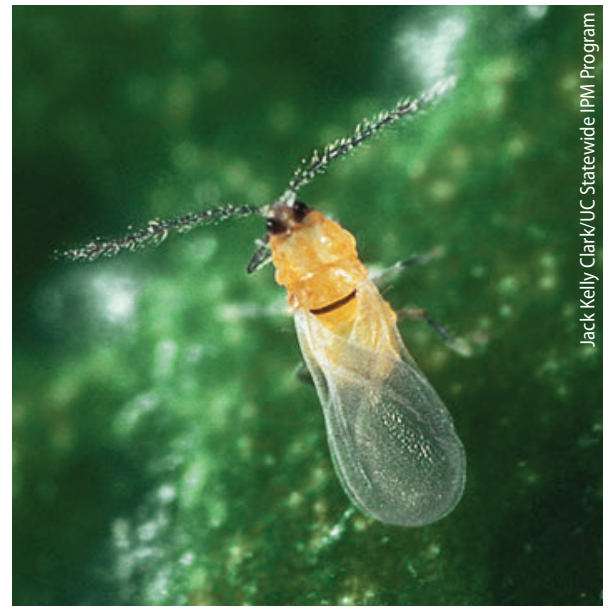

In a probability analysis for the use of $A$. melinus to control California red scale (shown, male), survey respondents with more citrus acreage were more likely to release the biological control agent.

pest control information, perhaps by making other sources more accessible or appealing.

Lastly, the variation across ethnic groups merits consideration. Asian respondents were less likely to rely on A. melinus, and summary statistics suggest that Latino growers may rely less on pest control provided by beneficial insects than white growers, although this was not confirmed in the formal statistical analysis. At the time of our survey, detailed information on $A$. melinus releases could only readily be found in English, which favors growers whose first language is English. While ethnicity should not be conflated with English-language skills, many Cooperative Extension documents in California are translated into various languages, suggesting that there are growers who benefit from information in other languages. Providing instructions on $A$. melinus releases in additional languages might make it easier for more growers to incorporate control provided by $A$. melinus into their pest management programs.

\section{K.A. Grogan is Assistant Professor, Food and} Resource Economics Department, University of Florida; and R.E. Goodhue is Professor, Department of Agricultural and Resource Economics, UC Davis, and Member, Giannini Foundation of Agricultural Economics.

The authors thank Karen Klonsky and Richard De Moura for input on survey content and format, the respondents for completing the survey, and the UC Giannini Foundation of Agricultural EConomics and the Jastro-Shields Award for funding. The authors also thank Lisa Bennett, Christine Carroll, Sarah Flores, Conner Mullally, Katie Pittenger, Libby McNiven, Ricky Volpe and Cassondra Yarlott for invaluable help with assembling the survey.

\section{References}

Congdon BD, McMurtry JA. 1988. Prey selectivity in Euseius tularensis (Acari: Phytoseiidae). Entomophaga 33(3):281-7.

Fake C, Klonsky KM, De Moura RL. 2008. Sample Costs to Establish a Mandarin Orchard and Produce Mandarins. UC Cooperative Extension MD-IR-08. IntermountainSierra Nevada Foothills. 22 p. www.coststudies.ucdavis. edu/files/MandarinIR2008.pdf.

Grafton-Cardwell EE. 1997. Manipulation of E. tularensis for improved thrips control. Citrograph 82(6):8.

Grafton-Cardwell EE, Eller A, O'Connell N. 1995. Integrated citrus thrips control reduces secondary pests. Cal Ag 49(2):23-8.

Grafton-Cardwell EE, Morse JG, O'Connell NV, et al. 2009. UC IPM Pest Management Guidelines: Citrus. UC ANR Pub 3441. Oakland, CA. 196 p. www.ipm.ucdavis.edu/ PMG/selectnewpest.citrus.html.

Grafton-Cardwell EE, Ouyang Y. 1995a. Augmentation of Euseius tularensis (Acari: Phytoseiidae) in citrus. Environ Entomol 24(3):738-47.

Grafton-Cardwell EE, Ouyang Y. 1995b. Manipulation of the predacious mite, Euseius tularensis (Acari: Phytoseiidae), with pruning for citrus thrips control. In: Parker BL, Skinner M, Lewis T (eds.). Thrips Biology and Management New York, NY: Plenum Pr. p 251-4.

Grafton-Cardwell EE, Ouyang Y, Striggow RA. 1999. Predacious mites for control of citrus thrips, Scirtothrips citri (Thysanoptera: Thripidae), in nursery citrus. Biol Control 14:29-36.
Hoffmann RW, Kennett CE. 1985. Effects of winter temperatures on the sex ratios of Aphytis melinus (Hym: Aphelinidae) in the San Joaquin Valley of California. Entomophaga 30(2):125-32.

Jones SA, Morse JG. 1995. Use of isoelectric focusing electrophoresis to evaluate citrus thrips (Thysanoptera: Thripidae) predation by Euseius tularensis (Acari: Phytoseiidae). Environ Entomol 24(5):1040-51.

Kennett CE, Flaherty DL, Hoffman RW. 1979. Effect of wind-borne pollens on the population dynamics of Amblyseius Hibisci (Acarina: Phytoseiidae). Entomophaga 24(1):83-98.

Kennett CE, Hoffman RW. 1985. Seasonal development of the California red scale (Homoptera: Diaspididae) in San Joaquin Valley citrus based on degree-day accumulation $J$ Econ Entomol 78(1):73-9.

Khan I, Morse JG. 2006. Impact of citrus thrips chemical treatments on the predatory mite Euseius tularensis. J Appl Entomol 130(6-7):386-92.

Luck RF. 1995. California red scale. In: Nechols J (ed.) Biological Control in the Western United States. UC ANR Pub 3361. Oakland, CA. 366 p.

McMurtry JA, Shaw JG, Johnson HG. 1979. Citrus red mite populations in relation to virus disease and predaceous mites in Southern California. Environ Entomol 8(1):160-4

Morse JG, Luck RF, Grafton-Cardwell EE. 2006. The evolution of biologically based integrated pest management in California citrus: History and perspective. UC Plant Prot Q 16(4):1-11.
O'Connell NV, Kallsen CE, Klonsky KM, De Moura RL. 2010. Sample Costs to Establish an Orchard and Produce Lemons. UC Cooperative Extension LM-VS-10. San Joaquin Valley-South. 24 p. www.coststudies.ucdavis.edu/files/ lemonvs10.pdf.

Smith EH, Kennedy GG. 2002. History of pesticides. In: Pimentel D (ed.). Encyclopedia of Pest Management. New York, NY: CRC Pr. 929 p.

[UCCE] UC Cooperative Extension. 2003. Crop Profile for Citrus in California. 107 p. www.ipmcenters.org/ cropprofiles/docs/cacitrus2.pdf.

[UC IPM] UC Integrated Pest Management. 2003. Natural Enemies Gallery: Aphytis spp. 1 p. www.ipm.ucdavis.edu/ PMG/NE/aphytis_melinus.html.

UC IPM. 2010. About UC IPM. www.ipm.ucdavis.edu/ IPMPROJECT/about.html.

[USDA] US Department of Agriculture. 2008. 2008 California Citrus Acreage Report. Sacramento, CA. 3 p. www.nass.usda.gov/Statistics_by_State/California/ Publications/Citrus/200811 citac.pdf.

Weeden CR, Shelton AM, Hoffman MP. 2007. Biological Control: A Guide to Natural Enemies in North America. www.nysaes.cornell.edu/ent/biocontrol (accessed February 2010).

Yu DS, Luck RF. 1988. Temperature-dependent size and development of California red scale (Homoptera: Diaspidae) and its effect on host availability for the ectoparasitoid Aphytis melinus DeBach (Hymenoptera: Aphelinidae). Environ Entomol 17(2):154-61. 